Fórum rovatunkban a Közjavak folyóirat korábbi számaiban megjelent tanulmányokhoz érkezett hozzászólásokat, vitaindítókat, reflexiókat, megjegyzéseket közöljük. A közös gondolkodás alapjainak továbbépítéséhez kíván fórumot biztosítani, továbbá a közjogi kutatások aktuális kérdéseinek megvitatásához, közvetlenül teret adva az aktuális témákkal kapcsolatos hírek megjelenésének, valamint a szakmai vélemények és különböző álláspontok közlésének a különböző jogágak közötti szabad és kötetlen kommunikáció jegyében.

\title{
A JOGALKOTÁS SZAKSZERŰSÉGE ÉS A JOG KÖZÉRTHETŐSÉGE*
}

\author{
Bartha Ildikó - Bordás Péter ${ }^{l}$
}

2017. június 14-én került megrendezésre az MTA ÁJB Közjogi Albizottsága által szervezett tudományos vitaülés, melynek témája a jogalkotás szakszerüsége és a jog közérthetösége volt. A rendezvény alapgondolatát az a kérdés adta, hogy hogyan beszélhetünk a mai társadalmi, gazdasági, kulturális egyenlötlenségek láttán jogegyenlőségröl, a joghoz való hozzáféréséröl, tisztességes eljárásról szakszerütlenül megalkotott jogszabályok mellett. A jogszabálytervezetek sem elözetes, sem párhuzamos, sem utólagos vizsgálata nem tudott gyakorlattá válni Magyarországon mindez nagy részben a kormányzás módjából, kultúrájából, hagyományaiból adódik. További problémát jelent, hogy jogszabályokban, közigazgatási határozatokban, bírósági ítéletekben vagy a jogi eljárások során használt jogi nyelv a laikusok számára gyakran érthetetlen, követhetetlen szövegfolyamként jelenik meg. A Közjogi Albizottság tudományos ülésén e felvetések közjogi alapjait vitattuk meg.

A beszélgetés moderátora Horváth M. Tamás (DE ÁJK, MTA-DE Közszolgáltatási Kutatócsoport) volt, aki a megnyitó gondolataiban kiemelte az egyes tudományos mühelyek közötti együttmüködés fontosságát, melynek megvalósulását a Közjogi Albizottság kiemelten fontosnak tartja és támogatja.

A vitaindító gondolatok keretében három előadást hallgathattak meg az érdeklődők.

Szabó Miklós (ME ÁJK) A jogi nyelv logikai alapstruktúrája címmel tartott előadást, valamint bemutatta a "A tisztességes eljárás nyelvi aspektusai" c. OTKA projekt kutatási eredményeit. A kutatás alapkoncepciója elkülöníti a szaknyelvet és a természetes nyelvet, kiemelve a jogi szaknyelv és a logika tudományának szoros

\footnotetext{
${ }^{*}$ DOI 10.21867/KjK/2017.3.7.

${ }^{1}$ Dr. Bartha Ildikó, egyetemi docens, DE ÁJK, MTA-DE Közszolgáltatási Kutatócsoport; Dr. Bordás Péter, tudományos segédmunkatárs, MTA-DE Közszolgáltatási Kutatócsoport
} 
kapcsolatát, és ezzel együtt a grammatikai értelmezésen túlmenő logikai értelmezés meghatározó szerepét.

Ezt követően a Jogi szövegtípusok. Egy lehetséges osztályozás címmel Ződi Zsolt (MTA TK JTI) vetette fel gondolatébresztő hozzászólását. E rendszerben alapvetően két réteget: a jogforrásokat és a jog működéséhez szükséges szövegek csoportját különíthetünk el. Az osztályozás további rétegeinek feltárása során többek között arról is szó volt, hogy hogyan képződik, illetve mitől érthető egy jogi szöveg, és milyen szerepe lehet a Google-nek a jogi szövegek értelmezésében.

\section{Jogi szövegtípusok osztályozása}

1. ábra

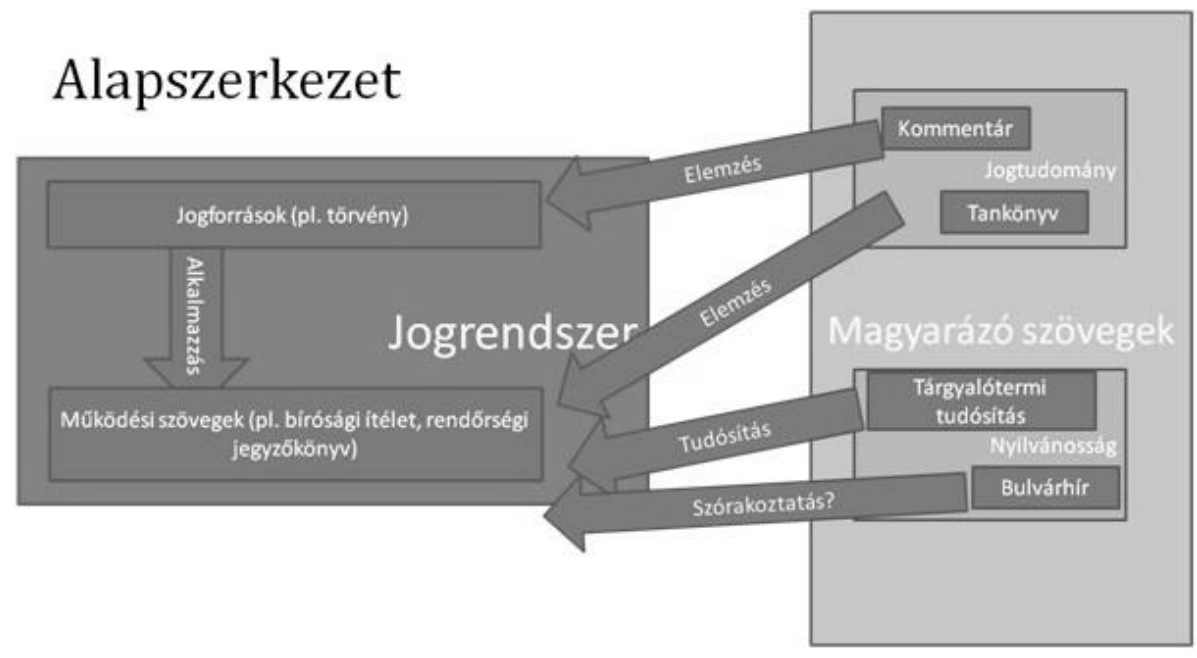

Forrás: Ződi Zsolt: Jogi szövegtípusok. Egy lehetséges osztályozás. Az MTA ÁJB Közjogi Albizottság 2017. június 14-i ülésén elhangzott előadás anyaga

A vitaindítók keretében végül Vinnai Edina (ME ÁJK) tartotta meg előadását $A$ jogi nyelv rétegei, a professzionális és laikus nyelv találkozása címmel. A jogi nyelv 1) tételes jogi, illetve 2) jogalkalmazás során használt rétegeit megkülönböztetve mind az írásbeli megnyilvánulások, mind pedig a szóbeli eljárások során vizsgálta a professzionális és a laikus nyelv találkozásának eseteit. Az előadásban szó volt a téma szempontjából releváns egyéb kezdeményezésekről is, így a bírósághoz való hozzáférés egyszerüsítése érdekében 2017-ben indított "közérthetőség éve" programról, ${ }^{2}$ valamint a közérdekü fogalmazás kérdésével foglalkozó vilagosbeszed.hu honlapról, amely többek között közigazgatási határozatok elemzésével is foglalkozik.

Majd két előzetesen felkért hozzászóló ismertette álláspontját. Először Tóth Judit (SZTE ÁJK) fejtette ki véleményét a minőségi jogalkotás közjogi keretei vagy kényszerei témakörében, s kitért arra, hogy milyen minőséget meghatározó szempontok és követelmények vannak/lehetnek egy jogi szöveggel szemben.

\footnotetext{
${ }^{2}$ http://www.manysi.hu/hirek/56/kozerthetoseg_a_birosagokon/?lang=hu
} 
Másodikként A választás szabadsága címmel Józsa Zoltán (SZTE ÁJK) vetett fel igen fontos vitaébresztő gondolatokat, többek között arról a kérdésröl, hogy a jog (jogi szövegezés) eszközével miként lehet szakmai "köntösbe" bújtatni egy valójában politikai döntést.

Végül a jelenlévők osztották meg a témához kapcsolódó eltérő álláspontjaikat, mely során jó volt látni, hogy nem csak a jogtudomány egyes ágainak oldaláról, hanem más tudományok (így a nyelvészet) szemszögéböl is eltérő érvek és szempontok mellett lehet megítélni a témát és a problémakört.

\title{
A vitaülés háttéranyagául az alábbi tanulmányok szolgáltak:
}

- Szabó Miklós: A jog nyelvi erőtere. In: Szabó Miklós (szerk.): A jog nyelvi dimenziója (2015, Miskolc, Bíbor Kiadó), 179-188. old.

- Vinnai Edina: Az első ,jog és nyelv” kutatás hazánkban. Alkalmazott Nyelvészeti Közlemények, Miskolc, IX. évfolyam, 1. szám (2014) 60-67. old.

- Ződi Zsolt: Alkalmas-e a Google jogi problémák megoldására? In: Szabó Miklós (szerk.): A jog nyelvi dimenziója (2015, Miskolc, Bíbor Kiadó), 283296. old.

- Józsa Zoltán: A választás szabadsága. (kézirat)

- Tóth Judit: A minőségi jogalkotás közjogi keretei vagy kényszerei. (kézirat)

\section{A KÖZPÉNZEK KELETKEZÉSKORI VÉDELMÉRŐL*}

\author{
Valentényi-Szilágyi Bernadett ${ }^{3}$
}

2017. szeptember 21-én, csütörtökön a Debreceni Egyetem Állam- és Jogtudományi Kara „A közpénzek keletkezéskori védelméröl” címmel tartott konferenciát, mely az Igazságügyi Minisztérium által támogatott "A Közpénzek keletkezéskori védelmének föbb területei" címü projekt eredményeit mutatja be. A projekt 2017. január 1-én indult, és Prof. Dr. Horváth M. Tamás, tanszékvezető egyetemi tanár szakmai irányítása mellett négy további kari oktató vett részt benne, akik egyben a konferencia előadói is voltak (Bartha Ildikó, Madai Sándor, Varga Judit és Bordás Péter). A kutatás fókuszában a közpénzek védelmének hazai és nemzetközi jogi szabályozása áll. Azt vizsgálja, hogy milyen eszközök állnak rendelkezésre a központi és a helyi kormányzati szinten, amelyek növelik a közpénzek, a különböző kormányzati felhasználású erőforrások

\footnotetext{
${ }^{*}$ DOI 10.21867/KjK/2017.3.8.

${ }^{3}$ Dr. Valentényi-Szilágyi Bernadett, egyetemi adjunktus, DE ÁJK
} 